much on the level now being worked. Drillings to a depth of $250 \mathrm{ft}$. below the present level showed a continuation of the salt deposit.

The excursion to the mine was made over the Southern Pacific line by special train, Ior persons making the trip. A box lunch was furnished on the train before arrival at the mines. Delicious refreshments were served by Mr. Myles, owner of the mine; ice cream and cooling drinks were plentiful on the return trip. As the route passed through sugar plantations and truck farms, the journey gave a good idea of the importance and extent of agriculture in Louisiana.

\section{INDUSTRIAL CHEMISTS AND CHEMICAL ENGINEERS DIVISION AMERICAN CHEMICAL SOCIETY MINUTES OF NEW ORLEANS MEETING}

The first meeting of the Division was devoted to the Public Symposium held at Tulane University and was presided over by Vice-chairman H. E. Howe. The program of papers is given on page 442 .

The regular divisional meeting was held at the Grunewald Hotel, New Orleans, La., April 2, I915, with Vice-chairman $\mathrm{H}$. E. Howe presiding.

The Secretary reported for the Chairman and the Executive Committee the appointment of the following committees:

Standard Specifications and Methods of Analysis-A. M. Comey, J. O. Handy, Robert Job, F. G. Stantial.

Non-ferrous Metals and Alioys, a Sub-committee of preceding Committee-Wm. Price, Chairman; Allen Merrill, Geo. L. Heath, Gilbert Rigg. Bruno Woichiechowski.

Soap Prodicts--Archibald Campbell, Chairman; C. P. Long, J. R. Powell, Percy H. Walker.

GLYCERINE, a Sub-Commitee of preceding Committee-A. C. Iangmuir, Chairman; W. H. Low, S. S. Emery, R. E. Devine, J. W. Loveland, A. M. Comey.

NAyal Stores-J. E. Teeple, Chairman; other members not yet selected. ALUM-W. M. Booth, Chairman: Chas. P. Hoover, Wm. C. Carnell.

Platincm-W. F. Hillebrand, Chairman; Percy H. Walker, H. T. Allen.

The Secretary reported on the financial condition of the Division as follows

Balance on hand April 6 ,

$1914 \ldots \ldots \ldots \ldots \ldots \ldots$
Received $\ldots \ldots \ldots \ldots \ldots$

$\$ 68.02$

1.00

Expenditures for printing

postage, etc......... \$25.55

Total Funds....... $\$ 69.02$

Balance on HaNd April $1,1915 \ldots \ldots \ldots \ldots \$ 43.47$

No Committee reports were received.

The reading of the papers was then continued in accordance with the program as given above.

The various methods for the analysis of alum which were offered by Wm. M. Booth, Chairman of the Committee on Alum, for discussion by the Division, were laid on the table as the time was too short for their attention.

Under new business the matter of the relation of the various committees to each other was brought $1 \mathrm{p}$ and it was moved by W. F. Hillebrand and seconded by A. H. Sabin that this matter be referred to the Executive Committee for settlement. The motion was carried.

LEHIGH UNIVERSITY

SO, BETHLEHEM, PA.

S. H. Salisbtry, JR., Secretary

\section{FERTILIZER DIVISION AMERICAN CHEMICAL SOCIETY} MINUTES OF NEW ORLEANS MEETING

The Meeting was called to order, Friday morning, April 2nd, in accordance with the official program, by Chairman Breckenridge. About thirty members attended.

PAUL, RudnICK, Chairman of the Committee on Research and Methods of Analysis, presented a report in which tentative standard methods for the sampling and analysis of phosphate rock were proposed. The degree of fineness of the coarse moisture sample was discussed. It was generally agreed that 4 mesh (Bureau of Standards specification), rather than 20 mesh, as proposed, would be fine enough. There was a lively discussion as to whether all silica should be made insoluble before determining sulfuric acid. The motion that the analysis be so conducted that all silica be made insoluble was finally carried. The motion to otherwise adopt the Committee's report was carried.

F. B. Carpenter, Chairman of Committee on Fertilizer Legislation, presented a report regarding some fertilizer laws now in force.

After the Committee Reports the papers listed in the above program on page 442 were read.

The paper by H. C. Moore was referred to the Committee of Research and Methods of Analysis.

\section{H. C. Moore, Secretary, pro-tem.}

\section{REPORT OF COMMITTFE ON FERTILIZER LEGISLATION}

During the past year, there have been no changes in the laws of the several states, which materially affect the fertilizer industry. There have been several bills presented in different states, which failed to pass and there is some legislation pending, but only a few minor changes have been noted, during the past twelve months.

There seems to be a growing tendency for the states to change from the brand tax to a tonnage tax. In some cases, this change has evidently been effected for the purpose of increasing the revenue, while in other instances, the reason assigned is to obtain statistical information, relative to the fertilizer business, which some companies now refuse to give. There seems to be no reason why any reputable company should be unwilling to furnish this information; on the contrary, the industry should be greatly benefited by having a reliable statistical bureau, through which it might be possible to ascertain the total tonnage of fertilizers sold in each state and the amount of plant food in these fertilizers. If such statistics were available, it is our opinion that they would become an important factor in increasing the sales of fertilizers.

In many of the states, the fertilizer laws have not been revised to meet present conditions, or when revision has been made, old forms have been copied. For instance, an expression commonly used is as follows: "It shall be unlawful to offer for sale any fertilizer or fertilizer material containing any hoof meal, horn, hair, leather, or any other substance in which the ammonia is largely unavailable." By this statement, it assumes that the ammonia in these articles is largely unavailable; while, as a matter of fact, from various tests, we find that hoof meal shows a satisfactory availability, and by modern practice, the ammonia in hair, leather, etc., can be made available by proper treatment.

When any of the state laws are undergoing revision, we should see that this form of expression is modified to read: "Any hoof meal, horn, hair, leather, or any other substance that has not been so treated as to render it largely available." This would allow the manufacturer to use materials which would cheapen the cost of fertilizers without in any way reducing their value.

Organic ammoniates, available for fertilizer purposes, are becoming scarcer each year, and if the manufacturer is restricted to such materials as Blood, Tankage, Cottonseed Meal, etc., the prices of ammoniated fertilizers will be largely increased in the future.

There seems to be little hope of getting a uniform law which will be applicable in the different states, but the fertilizer manufacturers should have the hearty co-operation of the agricultural departments in having only such laws enacted as will anply protect both the producer and consumer, without imposing unnecessary hardships on the manufacturer.

All unnecessary restrictions tend to increase the expense of production and must necessarily result in higher prices for the consumer.

J. E. BRECKENRIDGE PAUL RUDNICK , COMMITIEE ON

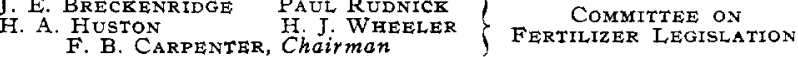


REPORT OF THE COMMITTEE ON RESTARCH AND ANALYTICAL METHODS-PHOSPHATE ROCK

The following tentative standard methods for sampling and determination of moisture, phosphoric acid and iron and alumina in phosphate rock are recommended to the Division.

METHODS OF SAMPLING AND DETERMINATION OF MOISTURE

I. GROSS SAMPLE- $A$ : CAR SHIPMENTS-IOO lb. sample per car.

I-SAMPLING FROM THE CAR: In sampling car șipments in the car at least ten scoopshovelsful, aggregating roo lbs., shall be taken from each car at approximately equal distances from each other so as to average the car. Care shall be taken to see that each scoopful shall cover the entire face of the pile from floor to top.

2-SAMPLING FROM THE CART OR BARROW: A small hand scoopful of $I$ to 2 lbs. shall be taken from each cart or barrow either as it is being loaded or as it leaves the car.

$B$ : CARGO SHIPMENTS- roo $\mathrm{lb}$. minimum sample per vessel.

I-SAMPLING IN HOISTING TUB: In sampling cargoes generally running from I0oo tons upward a small hand scoopful shall be taken from approximately every tenth tub before it is hoisted from the hold.

2-SAMPLING FROM CONVEYOR: If unloading is being done with automatic bucket and conveyor, periodical sections of the entire discharge of the conveyor shall be taken of such intervals and quantity as to give a sample equivalent to approximately one Ib. per each ten tons of cargo.

3-SAMPLING FROM CONVEYING VEHICLE: Samples shall be taken with a hand scoop from various cars at such regular intervals and in such quantities as to give approximately one 1b. for each ten tons of cargo.

II. IABORATORY SAMPIE-The resulting gross sample obtained by any one of the methods outlined shall be crushed to pass a four mesh screen, thoroughly mixed on a clean, hard surface and quartered down to a ro-lb. average sample.

$A$. CRUSHING-This Io-lb. sample shall all be crushed to pass an eight mesh screen.

B. MIXING AND QUARTERING-This eight mesh sample shall be carefully mixed and quartered down to two $2-1 \mathrm{~b}$. samples.

C. GRINDING-I-MOISTURE SAMPLE: One of these $2-1 \mathrm{~b}$. samples shall be held in an air-tight container. This sample is to be used for the determination of moisture.

2-ANALYTICAL SAMPLE: The other 2-1b. sample shall be further mixed and quartered down to a $2-$ or 4-oz. sample which is then to be ground to pass a 60 mesh screen or preferably a 65 mesh screen. This sample is to be used for the analytical determination.

NOTE: It is essential that the taking of the gross sample be done with small hand scoops and that the practice of taking the sample in the hand be absolutely prohibited, for it has been found that there is considerable selective action in the finer materials sifting through the fingers while a scoop retains the entire sample.

The dimensions of the screens referred to above are to be as follows:

$\begin{array}{ccc}\text { No. OF MESH } & \text { SIZE OF OpENING } & \text { DIAMETER OF WIRE } \\ & \text { Inches } & 0.065 \\ 4 & 0.185 & 0.032 \\ 8 & 0.093 & 0.0072\end{array}$

III. DETERMINATION OF MOISTURE-Moisture is to be determined on both the moisture sample and analytical sample. Of the moisture sample not less than Ioo grams are to be weighed out for each determination. Of the analytical sample approximately 2 grams are to be weighed out for each determination. Both are to be dried to constant weight at a temperature of $105^{\circ} \mathrm{C}$. in a well ventilated oven, preferably with a current of dry air passing through the oven. The containers in which moisture is determined should be provided with well fitting covers so that the samples may be cooled and weighed in the well covered container.
IV. CALCULATION OF RESULTS-The percentages of phosphoric acid and iron and alumina as determined on the analytical sample are to be calculated to a moisture-free basis and subsequently to the basis of the original sample as shown by the moisture content of the moisture sample.

\section{DETERMINATION OF PHOSPHORIC ACID}

REAGENTS-To be prepared as in Official Methods, A. O. A. C. Bureau of Chemistry, Bulletin I07 (Rev.), 1910, p. 2. Preparation of Reagents $(c),(d),(e)$ and $(f)$, except that the ammonium nitrate solution in $(d)$ is changed to 5 per cent instead of ro per cent.

METHOD OF SOLUTION-To 5 grams of the sample add $30 \mathrm{cc}$. of concentrated hydrochloric acid (sp. gr. I.2O) and IO cc. of concentrated nitric acid (sp. gr. I.42) and boil down to a syrupy consistency. The residue, which should be nearly solid after cooling, is taken up with 5 cc. of concentrated nitric acid and $50 \mathrm{cc}$. of water. Heat to boiling, cool, filter and make up to $500 \mathrm{cc}$. through the filter. This procedure eliminates practically all of the silica and it is necessary to filter as quickly as possible after digestion so as to avoid redissolving the silica.

DETERMINATION-Draw off an aliquot portion of $50 \mathrm{cc}$, corresponding to 0.5 gram, neutralize with ammonia, then add nitric acid until the solution is just clear. Add I5 grams of ammonium nitrate (free from phosphates), heat the solution to $50^{\circ} \mathrm{C}$. and add I5O cc. of molybdate solution. Digest at $50^{\circ} \mathrm{C}$. for 15 minutes with frequent stirring. Filter off the supernatant liquid and test the filtrate with molybdate solution to see if precipitation has been complete. (If not, add more molybdate to the filtrate and digest for $\mathrm{I}_{5}$ minutes longer.) Wash with 5 per cent ammonium nitrate solution by decantation, retaining as much of the precipitate as possible in the beaker. Dissolve the precipitate in the beaker in the least possible quantity of ammonium hydroxide (specific gravity 0.90 ) and dilute this solution with several times its volume of hot water. Dissolve the remainder of the precipitate on the filter with this solution, washing beaker and filter with hot water and keeping the volume of the filtrate between 75 and roo cc. Neutralize with hydrochloric acid, cool to room temperature and add 25 cc. of magnesia mixture from a burette, drop by drop, stirring vigorously with a rubber tipped rod, then add i $5 \mathrm{cc}$. of ammonium hydroxide (sp. gr. 0.90) and allow to stand for four hours or over night at room temperature. The time of standing may be reduced to two hours if kept in a refrigerator or still better in an ice water bath. Filter through a platinum or porcelain Gooch crucible, fitted with a platinum or asbestos mat carefully made and ignited to constant weight. Wash with 2.5 per cent ammonium hydroxide until practically free from chlorides; dry, ignite, cool and weigh as magnesium pyrophosphate. If desired, filtration may be made through an ashless filter paper, igniting in the usual manner. Calculate to $\mathrm{P}_{2} \mathrm{O}_{5}$ by multiplying by $0.6378(\log 80468)$.

\section{DETERMINATION OF IRON AND ALUMINUM TOGETHER AS PHOSPHATES}

I. SOLUTIONS REQUIRED: I-Hydrochloric acid ( I : I); prepared by mixing I part by volume of concentrated $\mathrm{HCl}$ (sp. gr. I.I9) with I part of distilled water.

2-A saturated solution of ammonium chloride, which should be filtered before use.

3-A 25 per cent solution of ammonium acetate, faintly acid to litmus paper.

4-A solution of ammonium phosphate (IO per cent), prepared by dissolving 20 grams of $\left(\mathrm{NH}_{4}\right)_{2} \mathrm{HPO}_{4}$ in $180 \mathrm{cc}$. of distilled water and filtering. (This should be prepared frequently in small quantity as it attacks glass containers on standing.)

5-A standard solution of ferrous ammonium sulfate, con- 
taining iron equivalent to about 0.0100 gram of $\mathrm{Fe}_{2} \mathrm{O}_{3}$ in $10 \mathrm{cc}$. and $50 \mathrm{cc}$. of conc. $\mathrm{HCl}$ per liter.

6-A solution of calcium and magnesium phosphates for blank determinations, prepared as follows: Dissolve 4 grams of $\mathrm{MgO}$ and 35 grams of $\mathrm{CaCO}_{3}$ (both free of iron and aluminum) in roo cc. of conc. $\mathrm{HCl}$, add an aqueous solution of 30 grams of $\left(\mathrm{NH}_{4}\right)_{2} \mathrm{HPO}_{4}$, make up to 2 liters and filter.

7-A solution of ammonium nitrate ( 5 per cent) for washing precipitates. About $400 \mathrm{cc}$. are required for each determination.

All reagents used should be as pure as practicable and all solutions should be free of suspended matter.

II. PREPARATION OF ROCK SOLUTION-Place 2.5 grams of pulverized rock with $50 \mathrm{cc}$, of I : I $\mathrm{HCl}$ in a graduated $250 \mathrm{cc}$. flask, the glass of which contains less than I per cent of iron and aluminum oxides. ${ }^{1}$ Boil gently with occasional shaking for $I$ hour in such a manner as to avoid concentrating the solution to less than half of its original volume, ${ }^{2}$ dilute, cool to room temperature, make up to volume and mix; filter immediately through a dry filter into a dry flask, discarding the first few cc. of the filtered solution.

Pipette a $50 \mathrm{cc}$. aliquot, representing 0.5 gram of rock, into a platinum dish and evaporate nearly to dryness. ${ }^{3}$ Cool, take up with a few cc. of water and when the salts are loosened from the dish, add $5 \mathrm{cc}$. of I : I sulfuric acid and evaporate to fumes. Increase the temperature and evaporate nearly to dryness." Cool, dilute with about $50 \mathrm{cc}$. of distilled water, add ro cc. of conc. $\mathrm{HCl}$ and heat, with occasional stirring, until sulfates are dissolved. Filter into a $600 \mathrm{cc}$. Jena glass beaker through a $9 \mathrm{~cm}$. paper (S \& S No. 597), washing the paper thoroughly with dilute $\mathrm{HCl}$ and hot water.

III. FIRST PRECIPITATION WITH AMMONIUM ACETATE-To the solution in the beaker, add $25 \mathrm{cc}$. of the standard iron solution when the amount of combined iron and aluminum oxides in the rock does not exceed 5 per cent and $50 \mathrm{cc}$. of the standard iron solution when the combined oxides exceed 5 per cent. ${ }^{5}$ Oxidize with about $3 \mathrm{cc}$. of bromine water and boil in covered beaker for about 15 minutes to expel the excess of bromine. Rinse cover and sides of beaker with distilled water and cool to room temperature.

(Run a blank determination containing ro $\mathrm{cc}$. of $\mathrm{r}: \mathrm{I} \mathrm{HCl}$, $25 \mathrm{cc}$. of the calcium and magnesium phosphate solution, and the same quantity of standard iron solution as is added to the rock solution.)

Add roo ce. of saturated ammonium chloride solution, ${ }^{6} 3 \mathrm{ce}$. of ro per cent ammonium phosphate solution, 2 drops of methyl

1 Experiments have shown that the solution cannot be made in fiasks made of glass containing a higher percentage of alumina, because the fluorine in the rock partially dissolves the glass and adds alumina to the solution. Neither "Nonsol," "Jena" nor "Weber's" resistant glass " $R$ " is suitable. Flasks made of glass containing little alumina, such as "Kavalier," "F $Z$ resistant glass" or other Bohemian glass of lower alumina content have proven satisfactory. See "Chemical Glassware," P. H. Walker, J. Am. Chem. Soc., 27, 865.

2 This may be accomplished by heating the flask over a low Bunsen flame or on a hot plate which is just hot enough to keep the solution boiling. A glass tube about 12 inches long by $8 / \%$ of an inch in diameter with a buib in the middle makes a very satisfactory condenser when placed in the neck of the flask.

${ }^{3}$ It is advisable to remove as much of the $\mathrm{HCl}$ as possible before adding sulfuric acid so as to minimize the chances of loss by effervescence or bumping. The evaporation may be conducted in glass beakers of low alumina content. Kavalier glass has been used satisfactorily. In no case should the evaporation be conducted in porcelain.

4 It is best to remove as much sulfuric acid as possible so that the calcium sulfate which might hold iron will dissolve readily in $\mathrm{HCl}$.

5 It has been found that when iron oxide is present in considerable excess over aluminum oxide the precipitation of the phosphates is more complete, the combined phosphates are more readily. ignited to constant weight, and the precipitate does not become red on ignition.

- Ammonium chloride in large quantity increases the solubility of calcium and magnesium phosphates and decreases the solubility of iron and aluminum phosphates. orange indicator and conc. ammonium hydrate (free of spangles and dissolved mineral matter) to alkaline reaction. Then add dilute $\mathrm{HCl}$ (about I : 20) drop by drop, with constant stirring, until the solution becomes faintly acid and the pink color of the methyl orange is just restored. ${ }^{1}$ Dilute to $450 \mathrm{ccc}^{2}$ with distilled water, heat to boiling, and add $25 \mathrm{cc}$. of 25 per cent ammonium acetate solution. Continue heating for about 5 minutes, after adding ammonium acetate, filter on a $12.5 \mathrm{~cm}$. ashless filter paper (S \& S No. 589 "White Ribbon" is suitable), in a 3 inch rapid filtering funnel, keeping the contents of the beaker and funnel hot. ${ }^{3}$ Wash 3 times with hot 5 per cent ammonium nitrate solution, each time cutting the precipitate loose from the filter and stirring it thoroughly with the stream from the wash bottle and filling to within about $1 / 4$ inch of its upper edge. About $30 \mathrm{cc}$. are required for each washing. Return the precipitate to the precipitating beaker by washing it out of the filter with a stream of hot water. Dissolve the precipitate with dilute $\mathrm{HCl}(\mathrm{I}: 6$ ), pouring about $50 \mathrm{cc}$. through the filter in successive washings and using about $25 \mathrm{cc}$. to wash down inside the beaker. Finish filter paper with distilled water.

IV. SECOND PRECIPITATION WITH AMMONIUM ACETATE-COOL the solution to room temperature, add $50 \mathrm{cc}$. saturated ammonium chloride solution, $4 \mathrm{cc}$. of ro per cent ammonium phosphate solution, 2 drops of methyl orange, and adjust acidity as before. Dilute to $300 \mathrm{cc}$. with distilled water. Heat to boiling, add $15 \mathrm{cc}$. of 25 per cent ammonium acetate solution and continue heating for about 5 minutes. Filter on the same paper as used for the first filtration, scrubbing the inside of the beaker with a rubber-tipped stirring rod and rinsing with hot 5 per cent ammonium nitrate solution. Wash the precipitate Io times with hot 5 per cent ammonium nitrate solution, each time cutting the precipitate loose, stirring it thoroughly as before and breaking up all lumps that it may contain. About $300 \mathrm{cc}$. of wash solution are required.

As a precautionary measure, boil the filtrate and washings from both the first and second precipitates, and recover any additional precipitate.

V. IGNITION OF PRECIPITATE-Transfer filter with precipitate to a weighed deep-form porcelain crucible $(40 \mathrm{~mm}$. in diameter is a good size) and heat gently over a low flame until the contents are dry, increase the temperature a little and continue heating until the paper is charred, increase the temperature again and continue heating until the paper is entirely burned. Ignite the uncovered" porcelain crucible for one-hour periods over blast lamp or No. 4 Meker burner to constant weight, each time cooling to room temperature in desiceator before weighing. Deduct the weight of blank from each determination, and after subtracting the weight of $\mathrm{FePO}$, equivalent to the amount of iron found in $0.5 \mathrm{gram}$ of rock by titration, calculate the remainder to $\mathrm{Al}_{2} \mathrm{O}_{3} . \quad \mathrm{AlPO}_{4} \times 0.4 \mathrm{I} 84=\mathrm{Al}_{2} \mathrm{O}_{3}$.

\section{DETERMINATION OF IRON}

I. SOLUTIONS REQUIRED-I-Standard Potassium Permanganate, $N / 4 \mathrm{O}$, containing $0.790{ }_{5}$ gram of $\mathrm{KMnO}_{4}$ per liter, and having a value of 0.001996 (or practically 0.002 ) gram of $\mathrm{Fe}_{2} \mathrm{O}_{3}$ per cc. Standardize with pure sodium oxalate (Bureau of Standards standard sample No. 40.)

2-Stannous Chloride. Dissolve 50 grams of the crystallized salt in Ioo cc. of hot conc. $\mathrm{HCl}$ and make up to $\mathrm{I}$ liter with distilled water.

I This method of adjusting acidity was suggested by F. B. Carpenter and was found to give satisfactory results.

2 All our work has confirmed Brown's statement (see Wiley's "Principles and Practice of Agricultural Analysis," 2nd edition, 1908, Vol. II, p. 245) that the separation from calcium under the conditions of the method depends upon sufficient dilution.

- The contents of the funnel will remain hot if the solution in the beaker is kept hot over a low flame and filtration is fairly rapid.

1 Heat over Bunsen to redness before placing over blast in order to prevent loss of precipitate by blowing out of crucible. 
3-Mercuric Chloride. Prepare a cold saturated solution.

4-Manganese Solution. (Preventive solution): (a)-Dissolve 200 grams of crystallized manganese sulfate in $1000 \mathrm{cc}$. of water. (b)-Pour slowly, with constant stirring, $400 \mathrm{cc}$. of conc. sulfuric acid into $600 \mathrm{cc}$. of water and add $1000 \mathrm{cc}$. of phosphoric acid of r.3 sp. gr. Mix solutions (a) and (b).

II. ANALYTICAL PROCEDURE-Determine iron according to Jones' and Jeffrey's modification of the Zimmermann-Reinhardt method ${ }^{1}$ as follows: Place in a $250 \mathrm{cc}$. beaker an aliquot of the rock solution, containing not more than $5 \mathrm{cc}$. of conc. $\mathrm{HCl}$, boil and reduce with the smallest possible excess of stannous chloride, added drop by drop while agitating the solution. Wash sides of beaker with distilled water and cool rapidly. Add Io cc. of mercuric chloride solution and stir vigorously for about 30 seconds. ${ }^{2}$ Pour the inixture into a large porcelain casserole or dish containing $20 \mathrm{cc}$. of the manganese solution in about $500 \mathrm{cc}$. of water which has just been tinted with the permanganate solution.

Titrate with $N / 40$ permanganate solution to original tint and correct result by the volume of $\mathrm{KMnO}_{4}$ required for a blank containing the same quantity of $\mathrm{HCl}$ (diluted), adding 2 or 3 drops of stannous chloride to the hot solution, cooling, adding to $\mathrm{cc}$. of mercuric chloride and titrating similarly.

When the rock solution contains carbonaceous matter it is necessary first to oxidize this with a little potassium chlorate, evaporate to dryness to eliminate chlorine, and redissolve with $5 \mathrm{cc}$. conc. $\mathrm{HCl}$ and about Io cc. of water.

Calculate the $\mathrm{Fe}_{2} \mathrm{O}_{3}$ found to $\mathrm{FePO}_{4}$, using the factor 1.8898 , and after deducting from the weight of combined phosphates found, calculate the difference $\left(\mathrm{AlPO}_{4}\right)$ to $\mathrm{Al}_{2} \mathrm{O}_{3}$.

$$
\begin{aligned}
& \left.\begin{array}{ll}
\text { F. K. CAMERON } & \text { A. J. PatTEN } \\
\text { J. E. BRECEENRIDGE C. H. JONES }
\end{array}\right\} \text { COMMITTEE ON RESEARCH } \\
& \text { PAUL RUDNICE, Chairman }
\end{aligned}
$$

\section{AMERICAN ELECTROCHEMICAL SOCIETY TWENTY-SEVENTH GENERAL MEETING} ATLANTIC CITY AND PHILADELPHIA, APRIL 22-4, I9I5

The Twenty-seventh General Meeting of the American Electrochemical Society was held at Atlantic City, N. J., and Philadelphia, Pa., April 22-4, I9r5. The meeting opened in Atlantic City with headquarters at the Hotel Chalfonte. Sessions on the 24th were held in the Harrison Laboratory, of the University of Pennsylvania, Philadelphia.

\section{PROGRAM OF PAPERS}

The American Electrochemical Society in Its External Relation. Presidential Address. F. A. IIDBURY.

Some Mechanical Analogies in Electricity. Experimental Iecture. W. S. FRANRLIN.

Effleiency of Iight Production. H. E. IvEs.

Experimental Lecture in the Harrison Iaboratories, University of Penneylvania. E. F. Smith.

1. Depolarization in LeClanché Cells. M. DE KAy ThOMpSON AND E. C. CROCKER. LEFY, JR.

2. The Thermal Conductivity of Refractories. Boyd Dud-

3. Chemistry in the Development and Operation of Flaming Arc Carbons. W. C. MOORE.

4. The Formation of Magnesium Suboxide in the Flectrolftic Preparation of Magnesium. F. C. Frary and H. C. Berman.

5. Flectrodeposition of Smooth Lead from Iead Nitrate Solutions. F. C. MATHERS AND ASA MCKinNeY. CROFT.

6. The Coagulation of Albumin by Electrolytes. W. D. BAN-

7. Neutralization of Absorbed Ions. W. D. BANCROFT

8. Fibrox. E. Weintraub.

1 A nalyst, 34 (1909), 306.

2 Barneby has shown that only a short interval of time is necessary between the addition of mercuric chloride and manganese sulfate, if the solution is thoroughly agitated. J. Am. Chem. Soc., 36 (1914), 143.
9. Thermo-Electromotive Force of Certsin Iron Alloys. T. E. FULLER.

10. Calorizing Motals. W. E. RUder.

11. Commercial Nitrogen Fixation. S. PEAcock.

12. Electroplating with Cobalt. H. T. KaLMUS, C. H. HARPEX AND W. L. SAvELL.

13. The Cyanamide Process. F. S. Washburs

14. Fixation of Atmospheric Nitrogen. L. L. Summers.

15. Cleaning and Plating in the same solution. O. P. Warts.

16. Some Problems in Copper Lesching. (General Discussion.)

17. On the Temperature of Reaction between Acheson Graphite and Magnesia. O. L. KOWALKE AND D. S. GRenFELL.

18. Lighting of Electrolytic Tank Rooms. R. E. Harrington.

The annual business meeting of the Society and the announcement of the election of officers for the coming year were held at the opening of the Thursday (22nd) afternoon session. Following the lecture by Prof. Franklin, Thursday evening, an informal social meeting was enjoyed in the Café Alamac.

The morning session on the $24^{\text {th }}$ was a joint session with the Illuminating Engineering Society, while that in the afternoon was held with the American Electroplaters' Society. The laboratories and museums of the University of Pennsylvania were visited by the members and guests.

\section{AMERICAN INSTITUTE OF CHEMICAL ENGINEERS TENTATIVE ITINERARY TO SAN FRANCISCO}

\begin{tabular}{lrrrrrr}
\multicolumn{1}{c}{ LEAve } & AUG. & \multicolumn{3}{c}{ ARrive } & \multicolumn{1}{c}{ AUG. } \\
New York & 6 & 5.04 P.M. & Chicago & 7 & 2.00. P.M. \\
Chicago & 7 & 6.00 P.M. & Colo. Springs & 9 & 7.00 A.M. \\
Colo. Springs & 10 & 6.45 P.M. & Grand Canyon 12 & 1.50 A.M. \\
Grand Canyon & 12 & 8.00 P.M. & San Diego & 13 & 6.00 P.M. \\
San Diego & 15 & 11.59 P.M. & Los Angeles & 16 & 3.30 A.M. \\
Los Angeles & 19 & 7.30 A.M. & Santa Barbara & 19 & 11.00 A.M. \\
Santa Barbara & 19 & 11.20 P.M. & Del Monte & 20 & 7.20 A.M. \\
Del Monte & 20 & 1.43 P.M. & San Francisco & 20 & 4.00 P.M. \\
San Francisco & 21 & 9.40 P.M. & Yosemite & 22 & 10.45 A.M. \\
& & & San Francisco & 25 & 8.28 A.M.
\end{tabular}

Monday, Aug. 16 to Thursday, Aug. I9-Excursions, sightseeing trips and joint session with the Southern California Section of the American Chemical Society.

Saturday, Aug. 2 I to Wednesday, Aug. 24-Members may visit the Fair for three days or take the trip to the Yosemite Valley.

Wednesday, Aug. 25 to Saturday, Aug. 28-Excursions and sessions of the Institute at the University of California and Leland Stanford University.

Members have the option of leaving San Francisco on Saturday, Aug. 28 at I0.30 A.M. by steamer for Astoria, reaching Portland on Sunday, Aug. 29, at 5 P.M., remaining in Portland one day and reaching Seattle on Tuesday, Aug. 3 I at 6.50 A.M., in time for the meeting of the American Chemical Society.

Members may also go by rail from San Francisco to Portland by the Southern Pacific Shasta route, a very beautiful scenic trip, but must decide at time of purchase of ticket from starting point, or take the following schedule:
LEAVE

San Francisci

Portland

Seattle

Butte

Anaconda

$\begin{array}{lr}\text { Aug. } 31 & 10.30 \text { A.M. } \\ \text { Sept. } 1 & 11.30 \text { P.M. } \\ \text { Sept. } 2 & 7.10 \text { P.M. } \\ \text { Sept. } 5 & 9.30 \text { A.M. } \\ \text { Sept. } 5 & 6.35 \text { P.M. }\end{array}$

6.35 P.M.
ARRIVE SEPT.

Portland 1 5.00 P.M. Seattle 26.50 A.M. Butte $\quad 3 \quad 9.28$ P.M. Anaconda 5 10.30 A.M.

Arrive Gardiner..........
Leave Gardiner.........

Members may omit the trip to the Yellowstone Park, arriving at Chicago, Tuesday, Sept. 7, 9.00 P.M. 